\title{
Analisis Pengaruh Biaya Terhadap Loyalitas Pengguna Mobile Banking Jenius Menggunakan Model Neural Networks
}

\author{
Ginanjar Ramadhan ${ }^{1}$, Aries Susanto $\mathrm{HT}^{2}$, Rinda Hesti $\mathrm{K}^{3}$
}

\begin{abstract}
Perbedaan biaya layanan seperti biaya transfer dan biaya administrasi yang diterapkan oleh beberapa institusi menimbulkan beberapa sikap dari nasabah, diantaranya terkait loyalitas pelanggan. Loyalitas merupakan perilaku yang ditunjukkan dengan penggunaan berulang-ulang yang didasarkan pada pengambilan keputusan. Mobile banking Jenius merupakan layanan perbankan yang diberikan oleh Bank Tabungan Pensiunan Nasional (BTPN). Belum diketahui faktor yang mempengaruhi loyalitas pengguna, membuat mobile banking Jenius belum maksimal dalam pengembangan produk, biaya juga menjadi salah satu faktor yang belum diketahui pengaruhnya sehingga keputusan perubahan biaya tidak diketahui. Status loyalitas pengguna mobile banking Jenius juga belum diketahui, sehingga keputusan untuk membuat program loyalitas belum dilakukan secara maksimal. Penelitian ini bertujuan untuk mengetahui faktor-faktor yang mempengaruhi loyalitas pengguna mobile banking Jenius menggunakan model Neural Networks yang dimodifikasi dengan menambahkan variabel cost. Populasi penelitian ini adalah pengguna mobile banking Jenius dengan teknik pengambilan sampel yaitu random sampling. Sementara analisis data menggunakan PLS-SEM dengan bantuan aplikasi Smart PLS 3.0. Hasil dari penelitian ini adalah switching barries, commitment, perceived quality, empathy, cost mempengaruhi perceived value dan customer satisfaction. Perceived value dan customer satisfaction berpengaruh terhadap trust dan customer loyalty. Hasil dari penelitian ini diharapkan menjadi bahan pertimbangan pengambilan keputusan Bank BTPN untuk meningkatkan loyalitas pengguna mobile banking Jenius.
\end{abstract}

Kata kunci- Loyalitas Pengguna, Mobile Banking, Neural Networks, PLS-SEM.

\section{PENDAHULUAN}

$\mathrm{P}$

Dengabah) layanan keuangan di Indonesia bermacam-macam, mulai dari layanan yang bertujuan untuk pinjaman hingga untuk simpanan. Nasabah dibebankan biaya seperti biaya administrasi, biaya bunga atau pajak, dan biaya transaksi setelah mendapatkan manfaat dari kegiatan perbankan. Penetapan biaya tersebut ditetapkan oleh bank

Received: 5 Agustus 2019; Revised: 17 September; Accepted: 20 September 2019.

G. Ramadhan , Prodi Sistem Informasi, UIN Syarif Hidayatullah Jakarta, Indonesia (e-mail: ginanjaramadhan@gmail.com)

http://journal.uinjkt.ac.id/index.php/aism sesuai dengan apa yang diharapkan oleh nasabah. Nasabah cenderung merasa puas apabila diperlakukan seperti apa yang diharapkan sehingga diharapkan menjadi nasabah yang setia dan loyal.

Terjadi perbedaan antar lembaga perbankan terkait biaya yang diterapkan kepada pelanggan, mulai dari biaya administrasi bulanan hingga biaya transfer yang dikenakan jika melakukan transfer uang antar bank [1]. Perbedaan biaya ini menimbulkan beberapa sikap dari nasabah, salah satunya adalah terkait kepuasan pelanggan. Terjadi hubungan antara biaya dengan kepuasan konsumen, semakin tinggi biaya yang dikeluarkan konsumen maka konsumen akan semakin puas [2]. Nasution juga mengatakan hal yang sama bahwa biaya berpengaruh terhadap kepuasan pelanggan [3]..Biaya mempengaruhi loyalitas pelanggan dan variabel biaya memiliki pengaruh terhadap kepuasan pelanggan $[4,5]$.

Selain itu, menurut Wahjono biaya berpengaruh terhadap customer satisfaction, biaya yang ditetapkan oleh perusahaan yang sesuai dengan harapan nasabah, cenderung nasabah merasa puas jika diperlakukan seperti apa yang diharapkan [6]. Menurut penelitian $\mathrm{Wu}$, Chen, Chen \& Cheng biaya saling berkaitan dan mempengaruhi nilai yang dirasakan pelanggan, membuat pelanggan melakukan pembelian kembali dan loyal terhadap perusahaan [7]. Menurut Monero dalam Mardikawati \& Farida disebutkan bahwa biaya merupakan salah satu komponen dari perceived value yang dapat menilai kinerja sebuah merek yang mampu menciptakan sebuah nilai [8].

Persaingan yang semakin ketat antar institusi penyedia produk dan layanan selain pengaruh globalisasi, faktor pelanggan yang semakin cerdas, sadar harga, banyak menuntut, kurang memaafkan, banyak produk yang melakukan pendekatan terhadap pelanggan, perkembangan teknologi komunikasi menjadi faktor persaingan antar produk atau penyedia jasa [9]. Dengan adanya hal tersebut,

A. S. H. Taufik, Prodi Sistem Informasi, UIN Syarif Hidayatullah Jakarta, Indonesia (e-mail: ariessht@ uinjkt.ac.id)

Rinda Hesti K, Prodi Sistem Informasi, UIN Syarif Hidayatullah Jakarta, Indonesia (e-mail: rinda.hesti@uinjkt.ac.id). 
perusahaan berupaya untuk terus meningkatkan dan memberikan keunggulan dari produk atau jasa demi terciptanya kepuasan serta loyalitas yang tinggi bagi para customer [10]. Loyalitas merupakan suatu perilaku yang ditunjukkan dengan pembelian berulang-ulang yang didasarkan pada pengambilan keputusan [11].

Salah satu fintech yang berkembang di Indonesia adalah mobile banking. Mobile banking adalah layanan bertransaksi yang disediakan oleh lembaga perbankan yang biasanya ada pada smartphone yang dapat mengurangi kegiatan kunjungan ke gerai bank dan dapat menghemat waktu dan biaya [12] Menurut Mobile Ecosystem Forum (MEF) 80 persen responden di Indonesia menyatakan bahwa sudah menggunakan layanan mobile banking [13].

Layanan mobile banking yang dikeluarkan oleh Bank Tabungan Pensiunan Nasional (BTPN) mengangkat konsep banking reinvented yang berarti bahwa semua aktivitas perbankan akan tercatat dalam satu aplikasi. BTPN mempunyai dua perbankan digital yang dibuat lebih sederhana dan lancar untuk nasabah yaitu BTPN Wow! dan Jenius [14]. Jenius mempunyai keunggulan dalam hal biaya transfer yang murah yaitu Rp. 3000 ke bank lain selain BTPN, dibandingkan dengan bank lain yang membebankan Rp. 6500 kepada nasabah untuk biaya transfer ke antar bank dan Rp. 4000 untuk biaya transfer antar bank di mesin Anjungan Tunai Mandiri (ATM) jaringan Link dan ditransfer antar jaringan Link [1].

Platform mobile banking Jenius dirilis pada bulan Agustus 2016. Dibandingkan dengan rekannya BTPN Wow! yang dapat diakses melalui telepon genggam sederhana, Jenius membutuhkan akses melalui smartphone. Jenius mempunyai target untuk menggaet nasabah yang lebih urban dan cerdas dalam penggunaan teknologi digital. Kombinasi penggunaan mobile app dan berbagai pilihan kartu debit yang bisa digunakan secara internasional dapat mempermudah nasabah dalam mengelola keuangan di setiap waktu dan di mana saja secara intuitif dan nyaman. Jenius tidak sekedar menawarkan layanan perbankan tradisional, tetapi menawarkan fitur-fitur dengan mengendalikan aspek keamanan, penetapan limit dan blokir kartu, serta pemanfaatan teknologi mutakhir teknologi enkripsi dan otentifikasi multi-level [14].

Namun, karena Jenius masih baru dengan jumlah nasabah berdasarkan laporan buku tahunan Bank BTPN yaitu sebesar 330.630, orang-orang masih belum mengetahui dan menggunakan Jenius. Berdasarkan penilaian yang ada di Google Playstore, Jenius sering mengalami error menjadi kendala pengguna Jenius untuk melakukan transaksi. Masih kurangnya persebaran mesin ATM Bank BTPN dan service point. Jenius menjadi kendala juga untuk penarikan tunai menggunakan mesin ATM dan pengaduan terkait kendala yang ada pada Jenius. Berdasarkan hal-hal tersebut di atas, maka dari itu perlu diukur sejauh apa loyalitas pengguna Jenius.

Dalam pembahasan mengenai loyalitas pelanggan, Ansari \& Riasi menyebutkan ada delapan faktor yang mempengaruhi loyalitas pelanggan yaitu kepuasan (satisfaction), hambatan berpindah (switching barries), kepercayaan (trust), komitmen (commitment), nilai yang dirasakan (perceived value), kualitas yang dirasakan (perceived quality), gambar intuitif (intuitive image), dan empati (emphaty) [15].

Untuk mengukur loyalitas pelanggan Ansari \& Riasi mengembangkan Model Neural Networks yang merupakan model yang meniru konsep dari jaringan saraf pada manusia sehingga dapat mengomputasikan pemodelan yang kompleks. Ada tiga lapisan yang dipakai yaitu lapisan pertama sebagai lapisan input, lapisan kedua sebagai lapisan tersembunyi, dan lapisan terakhir sebagai lapisan output. Lapisan input terdiri dari enam faktor dari delapan faktor yang mempengaruhi loyalitas pelanggan yaitu hambatan berpindah (switching barries), kepercayaan (trust), komitmen (commitment), kualitas yang dirasakan (perceived quality), gambar intuitif (intuitive image), dan empati (emphaty). Lapisan tersembunyi terdiri dari kepuasan (satisfaction) dan nilai yang dirasakan (perceived value) sedangkan lapisan outputnya adalah loyalitas pelanggan [15].

Beberapa penelitian yang melakukan analisis menggunakan Neural Networks untuk mengukur faktor-faktor yang mempengaruhi loyalitas pelanggan yaitu Deliana \& Rum, Greene, Morgan, \& Foxall, Larasati, DeYong, \& Slevitch, Lee, Rey, Mentele, \& Garver, Lotko, Korneta, Lotko, \& Longwic, Liébana-Cabanillas, Marinković, \& Kalinić, Badea (Stroie), Mobasheri, Alimomeni, \& Shahgholian, dan Zhang, Yuan, \& Liu [16-24].Dibandingkan dengan uji regresi, model Neural Networks lebih baik seperti pada penelitian Anggraeni, Hendrawan, \& Dewi didapatkan hasil dari proses training didapatkan bahwa nilai sebesar 93 s.d $100 \%$ sedangkan hasil uji regresi hasil prediksi berkisar pada 59 s.d 71\%. Dalam Ansari \& Riasi juga dikatakan bahwa model Neural Networks memiliki tingkat kesalahan estimasi yang lebih rendah dibandingkan dengan model regresi [25].

Berdasarkan pembahasan sebelumnya, pada penelitian ini akan meneliti faktor-faktor yang mempengaruhi loyalitas pengguna mobile banking Jenius menggunakan model Neural Networks dengan menambahkan satu variabel yaitu variabel biaya. Maka dari itu penulis tertarik untuk melakukan penelitian dengan judul "Analisis Pengaruh Biaya Terhadap Loyalitas Pengguna Mobile Banking Jenius Menggunakan Model Neural Networks".

http://journal.uinjkt.ac.id/index.php/aism 


\section{KaJian PENELITIAN}

\section{A. Konsep Dasar Analisis}

Analisis adalah kegiatan untuk mencari sebuah pola dan merupakan cara berpikir yang berkaitan dengan pengujian secara sistematis terhadap sesuatu untuk menentukan bagian, hubungan antar bagian, dan hubungan secara keseluruhan [26]. Analisis adalah suatu usaha untuk mengurai sebuah masalah atau kajian yang terfokus pada bagian-bagian (decomposition) sehingga susunan sesuatu yang diurai dapat tampak dengan jelas dan lebih terang untuk ditangkap maknanya atau dapat dimengerti perkaranya [27].

\section{B. Konsep Dasar Pengaruh}

Menurut Kamus Besar Bahasa Indonesia (KBBI) daring, pengaruh adalah daya yang ada atau timbul dari sesuatu baik itu orang maupun benda yang ikut membentuk watak, kepercayaan, atau perbuatan seseorang [28]. Menurut Badudu \& Zain pengaruh adalah daya yang membuat sesuatu itu terjadi, sesuatu dapat membentuk atau mengubah sesuatu yang lain, dan mengikuti kuasa atau kekuatan orang lain [29]. Dari uraian di atas dapat disimpulkan bahwa pengaruh adalah sebagai suatu daya yang ada atau timbul dari suatu hal yang mempunyai akibat atau hasil dan dampak yang ada.

\section{Konsep Dasar Loyalitas}

Loyalitas merupakan suatu perilaku yang ditunjukkan dengan pembelian berulang-ulang yang didasarkan pada pengambilan keputusan.,Loyalitas adalah sebuah perilaku konsumen yang dibangun atas pengalaman pembelian produk [11], bahkan termasuk pembelian produk yang dibeli bukan atas keputusan rasional [30]. Loyalitas merupakan pertanyaan bisnis yang dinilai penting, walaupun tidak tampak tetapi mempunyai posisi strategis dalam lingkungan bisnis yang kompetitif [31].

Berdasarkan uraian di atas, loyalitas merupakan suatu perilaku yang dibangun atas penggunaan produk yang berulang-ulang dan loyalitas merupakan nilai penting dan mempunyai posisi strategis dalam lingkungan bisnis..

\section{Electronic Commerce}

Electronic Commerce atau yang sering disebut dengan ecommerce adalah segala bentuk kegiatan ekonomi yang dilakukan melalui koneksi elektronik. $\neg$ E-commerce bukan hanya sekedar penggunaan teknologi informasi tetapi aliran komunikasi dari titik awal hingga titik akhir yang sepanjang rantai nilai seluruh proses bisnisnya dilakukan secara elektronik dan dirancang untuk melakukan pencapaian sebuah tujuan bisnis. Proses bisnis yang terjadi memungkinkan transaksi bisnis ke bisnis, bisnis ke konsumen, dan konsumen ke bisnis [32].

\section{E. Electronic Banking}

Electronic banking atau e-banking merupakan salah satu bagian dari electronic financing. Menurut UNCTAD e-banking merupakan penyebaran melalui layanan perbankan baik individu maupun kelompok mulai dari transfer bank, pembayaran dan pelunasan, pengumpulan data kredit dan lainnya. Arsitektur informasi e-banking dimodelkan sebagai arsitektur client-server. Seorang klien dapat beroperasi melalui personal computer yang terhubung dengan internet kemudian membuka situs e-banking khusus di banknya dengan memasukan kode khusus untuk melakukan transaksi [33].

\section{F. Mobile Banking}

Mobile banking adalah aplikasi perdagangan elektronik yang dibuat oleh lembaga keuangan atau bank yang memungkinkan penggunanya untuk melakukan transaksi keuangan dari jarak jauh dengan perangkat seluler [34]. Mobile banking merupakan layanan yang dilakukan untuk melakukan pembayaran seperti memeriksa rekening perbankan, melakukan transaksi, dan mentransfer uang [35].

\section{G. Neural Networks}

Neural Networks merupakan koneksi yang sederhana antar komponen yang berbeda. Dalam setiap lapisan, satu atau lebih unit pemrosesan (neuron buatan atau node) ada yang melakukan versi sederhana seperti neuron pada otak manusia [15]. Menurut Gardner \& Dorling mendefinisikan sebagai sistem sederhana yang saling berhubungan antar neuron yang mewakili pemetaan non linear antara vektor input dan vektor output[36].

Dalam neural networks terdapat tiga lapisan utama yaitu lapisan input, lapisan tersembunyi (hidden layer), dan lapisan output. Lapisan input merupakan terdiri dari neuron yang menerima data dan masukan dari variabel X. Semua neuron terhubung ke neuron yang ada di lapisan tersembunyi atau bisa langsung terhubung ke lapisan output jika model jaringan tidak menggunakan lapisan tersembunyi. Lapisan tersembunyi merupakan lapisan yang menerima dari lapisan input dan dengan mempertimbangkan bobot yang berbeda antara unit input dan unit tersembunyi. Lapisan ouput merupakan lapisan yang terdiri dari neuron yang menerima data dari lapisan tersembunyi atau lapisan input dan nilai yang dihasilkan merupakan nilai kalkulasi dari nilai X menjadi nilai Y [15].

Greene, Morgan, \& Foxall menjelaskan bahwa neural networks merupakan model yang kompleks dan mampu menjelaskan mengenai faktor-faktor yang berpengaruh dari pelanggan serta hasil analisisnya yang lebih baik dari pada model regresi biasa. Dalam Anggraeni et al., Larasati, DeYong, \& Slevitch, Badea (Stroie), dan Ansari \& Riasi juga menyatakan hal yang sama yaitu analisis menggunakan neural networks memiliki tingkat kesalahan estimasi yang lebih rendah dibandingkan dengan model regresi [23].

Model neural networks yang dikembangkan oleh Ansari \& Riasi merupakan model yang digunakan untuk menganalisis faktor-faktor yang mempengaruhi loyalitas pelanggan yang merupakan pengembangan dari peneliitian sebelumnya. Model Neural Networks ini terdiri dari lapisan input terdiri dari enam faktor dari delapan faktor yang mempengaruhi loyalitas pelanggan yaitu hambatan berpindah (switching barries), kepercayaan (trust), komitmen (commitment), kualitas yang dirasakan (perceived quality), gambar intuitif (intuitive image), dan empati (emphaty). Lapisan tersembunyi terdiri dari 
kepuasan (satisfaction) dan nilai yang dirasakan (perceived value) sedangkan lapisan outputnya adalah loyalitas pelanggan [15]. Ilustrasi neural network dapat dilihat pada gambar 1.

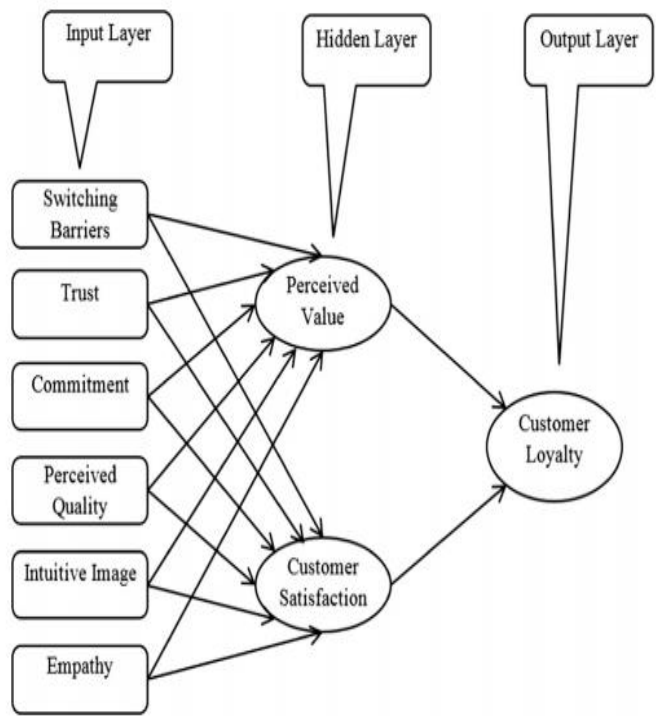

Gambar 1. Model Neural Networks.

\section{Metode Penelitian}

\section{A. Pendekatan Penelitian}

Pada penelitian ini digunakan pendekatan kuantitatif yang dikategorikan sebagai experimental research. Pengumpulan data dilakukan menggunakan instrumen berupa kuesioner yang disebarkan kepada pengguna mobile banking Jenius. Lalu analisis data secara statistik menggunakan beberapa tools, yaitu Word 2013 untuk penulisan laporan, Excel 2013 untuk pengolahan data demografi, Smart PLS Versi 3.2.8 untuk pengolahan data hasil penyebaran kuesioner, Visio 2016 untuk pembuatan gambar yang mendukung laporan penelitian, dan Mendeley Dekstop 1.19.3 untuk penulisan skripsi dan referensi yang digunakan peneliti sebagai acuan dalam penulisan laporan.

\section{B. Metode Pengumpulan Data}

Pada penelitian ini, pengumpulan data dilakukan dengan observasi, survey, dan studi pustaka. Sebelum melaksankan survei, peneliti melakukan observasi terlebih dahulu dengan melihat langsung mobile banking Jenius kemudian mengumpulkan data-data yang berhubungan dengan objek penelitian yaitu mobile banking Jenius. Pada penelitian ini, kuesioner disebarkan secara online dilakukan melalui sosial media seperti email, Instagram, Twitter, Whatsapp, Line, dan sejenisnya dengan bantuan Google Form untuk pengisian kuesioner. Kemudian penelitian dilakukan dengan studi pustaka yaitu mempelajari teori dari buku-buku dan situs-situs penyedia layanan terkait dengan objek penelitian yang akan dibahas.

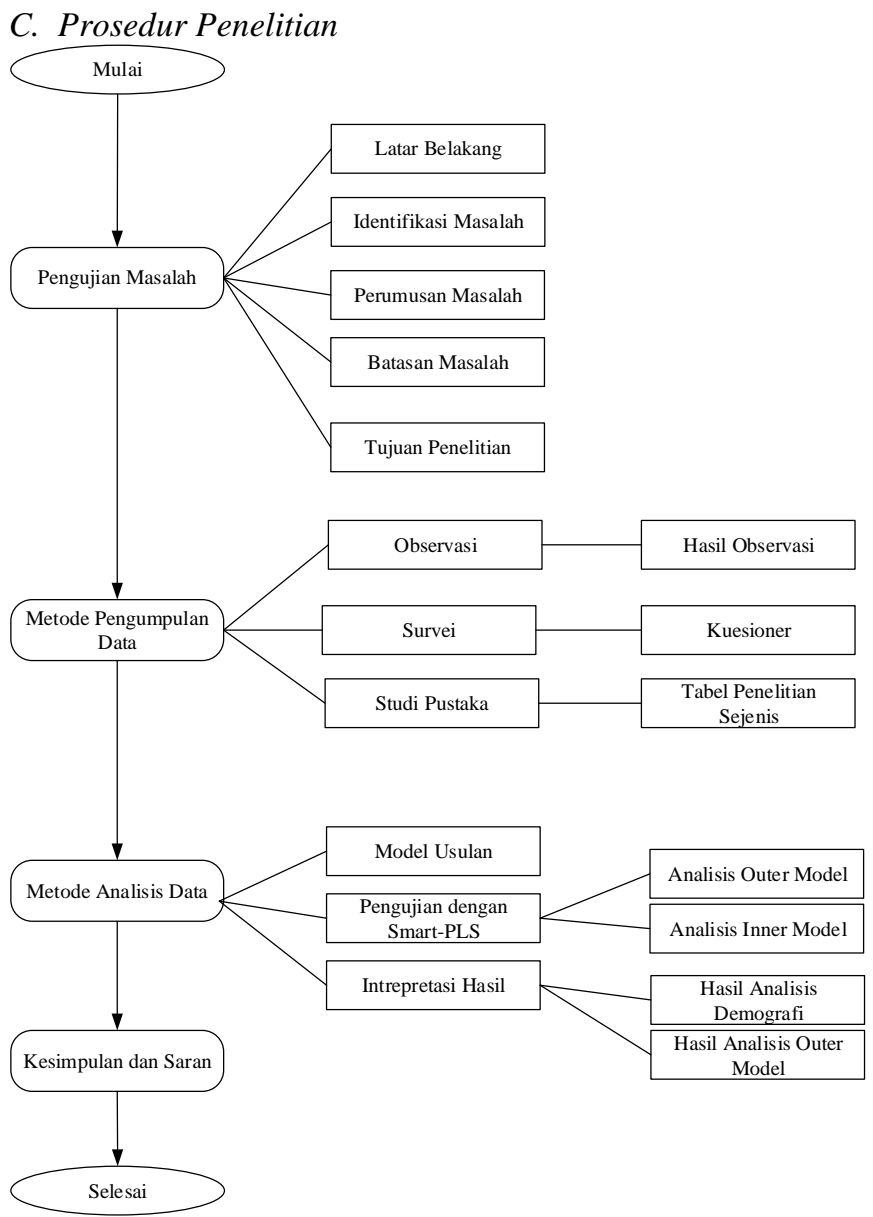

Gambar 2. Kerangka Berpikir.

Kerangka berfikir tercantum pada gambar 2, terdiri dari pengujian masalah, metode pengumpulan data, metode analisis data dan kesimpulan dan saran

\section{HASIL}

\section{A. Analisis Demografi}

Responden pada penelitian ini, berjenis kelamin perempuan lebih dominan yaitu sebanyak 158 orang. Sementara responden laki-laki berjumlah 92 orang. Pendidikan terakhir dimulai dari SMA/SMK/sederajat sampai S2. Dari hasil yang diperoleh, pendidikan terbanyak ada pada lulusan SMA/SMK/sederajat dengan jumlah 156 responden, pendidikan terkecil ada pada lulusan S2 dengan jumlah 2 responden. Untuk umur responden dimulai dari rentang umur 18 sampai dengan 25 tahun. Dari hasil yang diperoleh, dapat dilihat bahwa rentang umur yang terbanyak adalah rentang umur 18 s.d 25 tahun yaitu 201 responden, rentang umur terkecil yaitu 40 tahun ke atas dengan jumlah 2 responden. Hasil dari pekerjaan paling banyak adalah pelajar/mahasiswa berjumlah 173 responden dan paling sedikit adalah sebagai PNS/TNI/POLRI berjumlah 5 orang. Hasil uang saku/pendapatan responden dimulai dari rentang Rp. 1.000.000 s.d Rp. 3.000.000. Dari hasil yang diperoleh, dapat dilihat bahwa rentang uang saku/pendapatan yang paling banyak adalah Rp. 1.000.000 s.d Rp. 3.000.000 dengan jumlah 94 responden dan paling kecil adalah rentang pendapatan di atas 
Rp. 5.000.000 yaitu berjumlah 31 responden. Hasil dari lamanya penggunaan internet, diketahui bahwa responden dengan penggunaan internet paling banyak berada pada rentang 6 s.d 10 tahun sebanyak 116 orang $(46,4 \%)$ dan terkecil pengguna yang menggunakan internet kurang dari 1 tahun sebanyak 4 orang $(1,6 \%)$. Berdasarkan penggunaan mobile banking Jenius yang paling mendominasi adalah yang menggunakan mobile banking kurang dari 1 tahun yaitu sebanyak 180 orang dan sisanya menggunakan selama 1 s.d 3 tahun yaitu 70 orang.

\section{B. Analisis Model Pengukuran (Outer Model)}

Dalam melakukan analisis model pengukuran (outer model) dilakukan melaui empat tahap yaitu individual indicator reliability, internal consistency reliability, average variance extracted, dan discriminan validity.

1) Individual Indicator Reability

Pengujian ini dilakukan dengan melihat nilai outer loading yang menggambarkan besarnya korelasi antara setiap indikator dengan variabelnya. Outer loading dengan nilai di atas 0,7 dikatakan ideal [37]. Setelah melakukan perhitungan pada terhadap model penelitian, maka diperoleh nilai outer loading. Dari nilai outer loading tersebut, terdapat dua indikator yang dihapus, yaitu SB1 dan COS2 karena memiliki nilai dibawah 0,7.

2) Internal Consistensy Reability

Pengujian pada tahap ini dengan melihat hasil composite reliability (CR). Nilai CR 0,6 hingga 0,7 dikatakan dapat diterima, sedangkan nilai CR 0,7 hingga 0,9 dikatakan sangat memuaskan [37-39]. Nilai CR dapat di lihat pada tabel 1 dan diketahui bahwa nilai CR dari semua variabel di atas 0,7 sehingga memenuhi syarat dan valid untuk digunakan dalam model penelitian ini.

Tabel 1.

Hasil nilai Composite Reabilitty

\begin{tabular}{|c|c|}
\hline Variabel & $\begin{array}{l}\text { Composite } \\
\text { Reliability }\end{array}$ \\
\hline Customer Loyalty (CL) & 0,923 \\
\hline Commitment (COM) & 0,908 \\
\hline Cost (COS) & 0,913 \\
\hline Customer Satisfaction (CS) & 0,957 \\
\hline Empathy (EMP) & 0,893 \\
\hline Intuitive Image (II) & 0,9 \\
\hline Perceived Quality (PQ) & 0,917 \\
\hline Perceived Value (PV) & 0,913 \\
\hline Switching Barries (SB) & 0,93 \\
\hline Trust (TRU) & 0,944 \\
\hline
\end{tabular}

3) Average Variance Extracted

Pada tahap ini merupakan pengujian convergent validity selanjutnya dilakukan dengan melihat average variance extracted (AVE). Nilai minimal AVE adalah 0,5 yang menunjukkan bahwa convergent validity yang baik [37, 38,
40]. Hasil uji AVE dapat dilihat pada tabel 2 yang menunjukkan bahwa nilai AVE pada setiap variabel telah berada di atas ambang batas 0,5 sehingga semua nilai AVE dapat diterima.

Tabel 2.

Hasil nilai AVE

\begin{tabular}{|c|c|}
\hline Variabel & (AVE) \\
\hline Customer Loyalty (CL) & 0,75 \\
\hline Commitment (COM) & 0,712 \\
\hline Cost (COS) & 0,778 \\
\hline Customer Satisfaction (CS) & 0,849 \\
\hline Empathy (EMP) & 0,678 \\
\hline Intuitive Image (II) & 0,694 \\
\hline Perceived Quality (PQ) & 0,736 \\
\hline Perceived Value (PV) & 0,723 \\
\hline Switching Barries (SB) & 0,815 \\
\hline Trust (TRU) & 0,808 \\
\hline
\end{tabular}

4) Discriminant Validity

Pada tahap ini pengujian dilakukan dalam dua cara yaitu memeriksa cross loading, pertama dilakukan dengan membandingkan nilai outer loading indikator dengan variabelnya dan variabel pada blok lainnya. Nilai indikator dengan variabelnya harus lebih tinggi dari korelasi dengan variabel blok lainnya [39]. Nilai cross loading pada penelitian ini dapat dilihat pada dilihat bahwa nilai cross loading pada indikator terhadap variabelnya lebih tinggi jika dibandingkan dengan nilai cross loading pada variabel lainnya.

\section{Analisis Model Struktural (Inner Model)}

Pada analisis struktural model terdapat beberapa tahap pengujian, yaitu melihat nilai path coefficient, coefficient of determinatif, $t$-test, effect size, predictive relevance, dan relative impact. Berikut merupakan penjabaran dari setiap pengujian yang dilakukan.

\section{1) Path Coefficient}

Pengujian ini dilakukan dengan melihat nilai path coefficient yang memiliki ambang batas 0,1 untuk dapat dikatakan memiliki pengaruh terhadap model [39]. Nilai path coefficient antara variabel satu dengan variabel lainnya dapat dilihat pada tabel 3 berikut ini. Berdasarkan tabel 3 dapat diketahui bahwa nilai path coefficient dari 16 jalur, terdapat dua jalur yang 
Tabel 3.

Hasil nilai Patch Coefficient

\begin{tabular}{|c|c|c|}
\hline & Hubungan antar Variabel & $(\beta)$ \\
\hline $\mathrm{COM} \rightarrow \mathrm{CS}$ & & 0,142 \\
\hline $\mathrm{COM}>\mathrm{PV}$ & & 0,174 \\
\hline $\mathrm{COS}>\mathrm{CS}$ & & $\begin{array}{l}- \\
0,141\end{array}$ \\
\hline COS -> PV & & $\overline{0}, 083$ \\
\hline $\mathrm{CS}->\mathrm{CL}$ & & 0,587 \\
\hline CS $->$ TRU & & 0,439 \\
\hline EMP $>>C S$ & & 0,206 \\
\hline EMP -> PV & & 0,158 \\
\hline II $->$ CS & & 0,125 \\
\hline II -> PV & & 0,145 \\
\hline$P Q$-> CS & & 0,17 \\
\hline$P Q$-> PV & & 0,263 \\
\hline $\mathrm{PV}$-> CL & & 0,278 \\
\hline PV $->$ TRU & & 0,297 \\
\hline SB $->C S$ & & 0,248 \\
\hline SB -> PV & & 0,15 \\
\hline
\end{tabular}

memiliki nilai yang di bawah 0,1 yaitu COS -> CS $(-0,141)$ yang berarti jalur ini memiliki pengaruh negatif yang signifikan. Selain itu, COS -> PV $(-0,083)$ yang berarti jalur ini memiliki pengaruh negatif yang tidak signifikan.

\section{2) Coefficient of Determinant}

Pada pengujian ini, nilai $\mathrm{R}^{2}$ menggambarkan tingkat variasi perubahan variabel independen terhadap variabel dependen [39]. Berdasarkan tabel 4, diketahui bahwa dua variabel diklasifikasikan sebagai moderat yaitu PV $(0,646)$ dan TRU $(0,484)$, yang berarti bahwa switching barriers $(S B)$, commitment $(\mathrm{COM})$, perceived quality $(\mathrm{PQ})$, intuitive image (II), empathy (EMP), dan cost (COS) menjelaskan secara moderat yaitu 64,6\% dari varian PV. Sedangkan CS dan PV menjelaskan secara moderat yaitu $48,4 \%$ dari varian TRU. Dua variabel lain diklasifikasikan sebagai substansial yaitu CS $(0,685)$ dan CL $(0,676)$ yang berarti bahwa SB, COM, PQ, II, EMP, COS menjelaskan secara substansial yaitu $68,5 \%$ dari varian CS. Sedangkan PV dan CS menjelaskan secara substansial yaitu 67,6\% dari varian CL.
Tabel 4.

Hasil nilai coefficient of determinant

\begin{tabular}{ll}
\hline \hline \multicolumn{1}{c}{ Variabel } & $\mathrm{R}$ \\
& Square \\
\hline Customer Loyalty (CL) & 0,676 \\
Customet Satisfaction (CS) & 0,685 \\
Perceived Value (PV) & 0,646 \\
Trust (TRU) & 0,484 \\
\hline \hline
\end{tabular}

3) T-Test atau T-Statistic

Dalam pengujian t-test ini dilakukan dengan mode boostraping dengan uji two-tailed dimana tingkah signifikan yang digunakan adalah $5 \%$ dimana nilai $t$-test harus lebih besar dari 1,96 [37, 38]. Berdasarkan tabel 5. dapat diketahui bahwa terdapat dua jalur atau hipotesis yang ditolak karena memiliki nilai $t$-test di bawah 1,96 yaitu II $>$ CS $(1,775)$ dan II -> PV $(1,863)$ sementara 14 hipotesis lainnya diterima. Sedangkan dilihat dari nilai $p$ value, 16 hipotesis yang diterima, semuanya memiliki tingkat signifikansi 5\%. Sedangkan gambar 3 merupakan ilustrasi hasil dari hasil uji test

Tabel 5.

Hasil nilai T-Test

\begin{tabular}{|c|c|c|}
\hline & Hubungan antar Variabel & $\begin{array}{c}\text { T Statistics } \\
\text { (|O/STDEV|) }\end{array}$ \\
\hline $\mathrm{COM} \rightarrow \mathrm{CS}$ & & 2,477 \\
\hline $\mathrm{COM}->\mathrm{PV}$ & & 2,762 \\
\hline COS $>$ CS & & 2,86 \\
\hline COS -> PV & & 2,102 \\
\hline $\mathrm{CS} \rightarrow \mathrm{CL}$ & & 9,38 \\
\hline CS $->$ TRU & & 4,821 \\
\hline EMP $>$ CS & & 3,016 \\
\hline EMP -> PV & & 2,164 \\
\hline II $->$ CS & & 1,775 \\
\hline II -> PV & & 1,863 \\
\hline$P Q$-> CS & & 2,224 \\
\hline$P Q$-> PV & & 3,326 \\
\hline $\mathrm{PV}->\mathrm{CL}$ & & 4,3 \\
\hline PV $->$ TRU & & 3,028 \\
\hline $\mathrm{SB} \rightarrow \mathrm{CS}$ & & 4,713 \\
\hline SB $>$ PV & & 2,43 \\
\hline
\end{tabular}




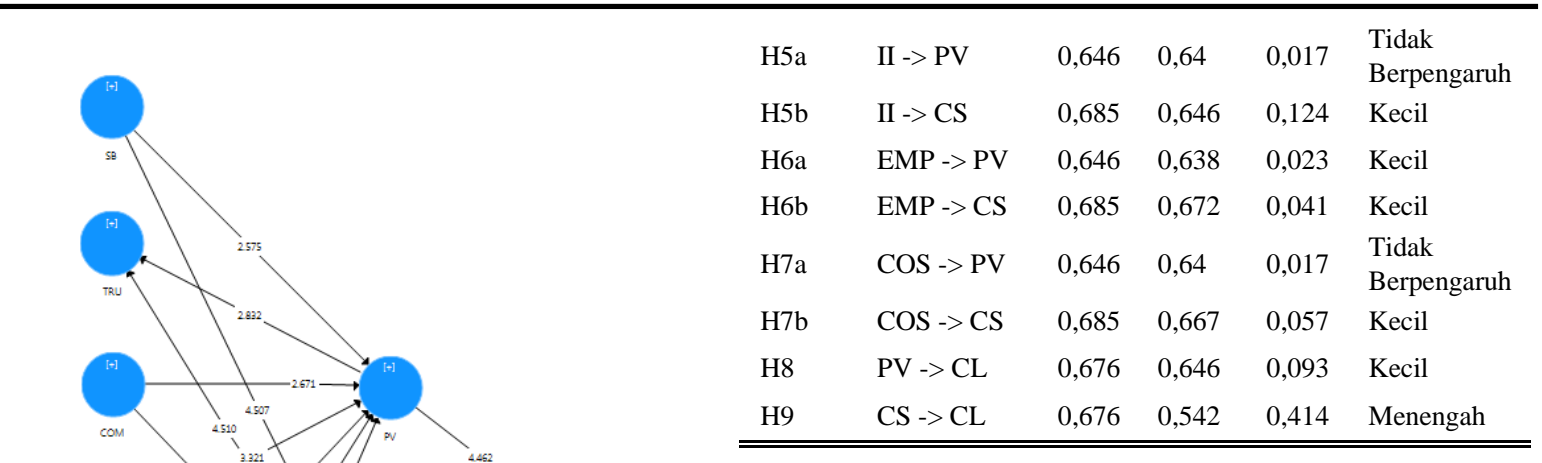

5) Predictive Relevance

Dalam pengujian ini menggunakan metode blindfolding untuk dapat memberikan bukti bahwa variabel tertentu yang digunakan dalam suatu model yang dibuat mempunyai prediktif (predictive relevance) dengan variabel lainnya dalam model tersebut. Nilai $\mathrm{Q}^{2}$ yang dihasilkan harus berada di atas nol. Hasil uji predictive relevance dapat dilihat pada tabel 7. berikut

Tabel 7.

Hasil nilai Predictive Relevance

\begin{tabular}{lc}
\hline \hline \multicolumn{1}{c}{ Variabel } & $\mathrm{Q}^{2}$ \\
\hline Customer Loyalty (CL) & 0,474 \\
Customer Satisfaction (CS) & 0,536 \\
Perceived Value (PV) & 0,431 \\
Trust (TRU) & 0,364 \\
\hline \hline
\end{tabular}

Dalam pengujian ini, menghitung nilai effect size untuk memprediksi pengaruh variabel tertentu terhadap variabel lainnya dalam struktur model. Nilai effect size memiliki ambang batas sekitar 0,02 untuk pengaruh kecil, 0,15 untuk pengaruh menengah, dan 0,45 untuk pengaruh besar. Sementara nilai effect size di bawah 0,02 mengindikasikan tidak memiliki pengaruh dalam struktur model $[37,38]$. Berdasarkan tabel 6. dapat diketahui bahwa hipotesis CS -> CL memiliki nilai effect size yang besar yaitu 0,414 yang menandakan bahwa hipotesis ini memiliki pengaruh yang menengah terhadap struktur model. Dua hipotesis yaitu II $>$ PV $(0,017)$ dan COS -> PV $(0,017)$ tidak memiliki pengaruh terhadap struktur model. Sedangkan 13 hipotesis lain memiliki pengaruh kecil terhadap struktur model.

Tabel 6.

Hasil nilai Effect Size

\begin{tabular}{cccccl}
\hline \hline & Hipotesis & & $f^{2}$ & \\
Hip & Jalur & $\mathrm{R}^{2}$-in & $\mathrm{R}^{2}$-ex & Z R $^{2}$ & Analisis $f^{2}$ \\
\hline H1a & SB -> PV & 0,646 & 0,636 & 0,028 & Kecil \\
H1b & SB -> CS & 0,685 & 0,658 & 0,086 & Kecil \\
H2a & PV -> TRU & 0,484 & 0,45 & 0,066 & Kecil \\
H2b & CS -> TRU & 0,484 & 0,41 & 0,143 & Kecil \\
H3a & COM -> PV & 0,646 & 0,634 & 0,034 & Kecil \\
H3b & COM -> CS & 0,685 & 0,677 & 0,025 & Kecil \\
H4a & PQ -> PV & 0,646 & 0,624 & 0,062 & Kecil \\
H4b & PQ -> CS & 0,685 & 0,675 & 0,032 & Kecil
\end{tabular}

6) Relative Impact

Pada pengujian ini, dilakukan dengan metode blindfolding untuk dapat mengukur $q^{2}$ yang menggambarkan relatif pengaruh sebuah keterkaitan antara prediktif sebuah variabel tertentu dengan variabel lainnya yang memiliki nilai ambang batas 0,02 untuk pengaruh kecil, 0,15 untuk pengaruh sedang dan 0,35 untuk pengaruh besar $[37,38]$. Untuk hasil uji relatif impact dapat dilihat pada tabel 8 berikut ini

Tabel 8.

Hasil nilai Relative Impact

\begin{tabular}{|c|c|c|c|c|c|}
\hline \multicolumn{2}{|c|}{ Hipotesis } & \multicolumn{3}{|c|}{$q^{2}$} & \multirow[b]{2}{*}{ Analisis $q^{2}$} \\
\hline Hip & Jalur & $\mathrm{Q}^{2}$-in & $\begin{array}{l}\mathrm{Q}^{2-} \\
\mathrm{ex}\end{array}$ & $q^{2}$ & \\
\hline $\mathrm{H} 1 \mathrm{a}$ & $\begin{array}{l}\text { SB - } \\
>\text { PV }\end{array}$ & 0,431 & 0,426 & 0,009 & $\begin{array}{l}\text { Tidak } \\
\text { Berpengaruh }\end{array}$ \\
\hline $\mathrm{H} 1 \mathrm{~b}$ & $\begin{array}{l}\text { SB - } \\
>\text { CS }\end{array}$ & 0,536 & 0,516 & 0,043 & Kecil \\
\hline $\mathrm{H} 2 \mathrm{a}$ & $\begin{array}{l}\text { PV - } \\
> \\
\text { TRU } \\
\text { CS - }\end{array}$ & 0,364 & 0,339 & 0,039 & Kecil \\
\hline $\mathrm{H} 2 \mathrm{~b}$ & $\begin{array}{l}> \\
\text { TRU }\end{array}$ & 0,364 & 0,309 & 0,086 & Kecil \\
\hline $\mathrm{H} 3 \mathrm{a}$ & $\begin{array}{l}\mathrm{COM} \\
-> \\
\mathrm{PV}\end{array}$ & 0,431 & 0,423 & 0,014 & $\begin{array}{l}\text { Tidak } \\
\text { Berpengaruh }\end{array}$ \\
\hline
\end{tabular}

http://journal.uinjkt.ac.id/index.php/aism 


\begin{tabular}{|c|c|c|c|c|c|}
\hline $\mathrm{H} 3 \mathrm{~b}$ & $\begin{array}{l}\mathrm{COM} \\
-> \\
\mathrm{CS}\end{array}$ & 0,536 & 0,531 & 0,011 & $\begin{array}{l}\text { Tidak } \\
\text { Berpengaruh }\end{array}$ \\
\hline $\mathrm{H} 4 \mathrm{a}$ & $\begin{array}{l}\mathrm{PQ}- \\
>\mathrm{PV}\end{array}$ & 0,431 & 0,417 & 0,025 & Kecil \\
\hline $\mathrm{H} 4 \mathrm{~b}$ & $\begin{array}{l}\text { PQ - } \\
>C S\end{array}$ & 0,536 & 0,529 & 0,015 & $\begin{array}{l}\text { Tidak } \\
\text { Berpengaruh }\end{array}$ \\
\hline H5a & $\begin{array}{l}\text { II -> } \\
\text { PV }\end{array}$ & 0,431 & 0,428 & 0,005 & $\begin{array}{l}\text { Tidak } \\
\text { Berpengaruh }\end{array}$ \\
\hline $\mathrm{H} 5 \mathrm{~b}$ & $\begin{array}{l}\text { II -> } \\
\text { CS }\end{array}$ & 0,536 & 0,534 & 0,004 & $\begin{array}{l}\text { Tidak } \\
\text { Berpengaruh }\end{array}$ \\
\hline H6a & $\begin{array}{l}\text { EMP } \\
-> \\
\text { PV }\end{array}$ & 0,431 & 0,427 & 0,007 & $\begin{array}{l}\text { Tidak } \\
\text { Berpengaruh }\end{array}$ \\
\hline H6b & $\begin{array}{l}\text { EMP } \\
-> \\
\text { CS }\end{array}$ & 0,536 & 0,526 & 0,022 & Kecil \\
\hline $\mathrm{H} 7 \mathrm{a}$ & $\begin{array}{l}\text { COS } \\
-> \\
\text { PV } \\
\text { COS }\end{array}$ & 0,431 & 0,427 & 0,007 & $\begin{array}{l}\text { Tidak } \\
\text { Berpengaruh }\end{array}$ \\
\hline $\mathrm{H} 7 \mathrm{~b}$ & $\begin{array}{l}-> \\
\mathrm{CS}\end{array}$ & 0,536 & 0,522 & 0,03 & Kecil \\
\hline H8 & $\begin{array}{l}\mathrm{PV}- \\
>\mathrm{CL}\end{array}$ & 0,474 & 0,454 & 0,038 & Kecil \\
\hline H9 & $\begin{array}{l}\text { CS - } \\
>\mathrm{CL}\end{array}$ & 0,474 & 0,382 & 0,175 & Sedang \\
\hline
\end{tabular}

\section{KESIMPULAN DAN SARAN}

Penelitian ini telah berhasil mengetahui pengaruh biaya terhadap loyalitas pengguna mobile banking Jenius, mengetahui faktor-faktor yang mempengaruhi loyalitas pengguna mobile banking Jenius, dan mengetahui status loyalitas pengguna mobile banking Jenius. Berdasarkan hasil pembahasan terkait faktor-faktor yang mempengaruhi loyalitas pengguna mobile banking Jenius menggunakan model Neural Networks, maka dapat disimpulkan bahwa :

1) Faktor mayoritas yang mempengaruhi loyalitas pelanggan mobile banking Jenius adalah kepuasan pelanggan (customer satisfaction) disusul oleh nilai yang dirasakan (perceived value). Selain itu diketahui bahwa biaya berpindah (switching barries), komitmen (commitment), kualitas yang dirasakan (perceived quality), empati (empathy), biaya (cost) mempengaruhi nilai yang dirasakan dan kepuasan pelanggan. Nilai yang dirasakan dan kepuasan pelanggan terpengaruh terhadap kepercayaan (trust) pelanggan, hal ini dilihat dari nilai t-test $>1.96$.

2) Hubungan antara cost terhadap customer satisfaction memiliki pengaruh negatif yang signifikan sedangkan hubungan antara cost terhadap perceived value memiliki pengaruh negatif yang tidak hal ini dapat dilihat dari nilai ( $\beta$ ) yang bernilai negatif dan nilai t-test $>1.96$.

3) Pengguna mobile banking Jenius akan terus menggunakan dan loyal terhadap mobile banking Jenius, karena nilai outer loading dari CL3 adalah 0.913.

Berdasarkan hasil temuan tersebut juga peneliti menganggap penelitian ini memberikan manfaat dan berkontribusi pada beberapa hal yang menjadi bahan referensi bagi Bank BTPN dalam meningkatkan loyalitas pengguna pada mobile banking Jenius, menjadi referensi untuk penelitian- penelitian yang berkaitan dengan pengukuran loyalitas pelanggan, serta mendorong pemanfaatan metode kuantitatif pada penggunaan model Neural Networks.

\section{REFERENSI}

[1] Flip. (2018). Biaya Transfer Antar Bank dan Tarik Tunai. Available: https://flip.id/biaya-transfer-antar-bank

[2] Y. Li, H. Liu., et al., "Customer's reaction to cross-channel integration in omnichannel retailing: The mediating roles of retailer uncertainty, identity attractiveness, and switching costs," Decision support systems journal, vol. 109, pp. 50-60, 2018.

[3] Nasution, S. M. Affandy., "The effect of price and service quality on customer satisfaction and loyalty customer waroeng steak and shake Medan," Proceedings of AICS-Social Sciences, vol. 7, pp. 342-347, 2017.

[4] N. Purnamasari, "Pengaruh Layanan Dasar, Layanan Canggih, Biaya, Program Loyalitas Terhadap Kepuasan Dan Loyalitas Nasabah Bank BCA Di Surabaya," STIE Perbanas Surabaya, 2016.

[5] D. Khadafi, "Analisis Faktor-Faktor Yang Mempengaruhi Kepuasan dan Implikasinya Terhadap Loyalitas Nasabah pada Bank BRI Cabang Demak," program Pascasarjana Universitas Diponegoro, 2008.

[6] S. Imam, Wahjono, "Manajemen pemasaran bank," 2010.

[7] Wu, Lei-yu, et al., "Perceived value, transaction cost, and repurchaseintention in online shopping: A relational exchange perspective," Journal of Business Research, vol. 67, no. 1, pp. 2768-2776, 2014.

[8] M. Woro, F. Naili, "Pengaruh Nilai Pelanggan dan Kualitas Layanan terhadap Loyalitas Pelanggan, melalui kepuasan pelanggan pada Pelanggan bus efisiensi (studi po efisiensi jurusan yogyakarta-cilacap)," Jurnal Administrasi Bisnis, vol. 2, no. 1, pp.64-75, 2013.

[9] R. Rachmawati, "Pengaruh Kepuasan Terhadap Loyalitas Pelanggan," TEKNOBUGA: Jurnal Teknologi Busana dan Boga, vol. 1, no. 1, pp. 6679, 2014.

[10] S. H. Winarno, B. Givan, Y. Yudhistira, "Determinan Loyalitas Pelanggan pada Operator Telepon Selular," Esensi: Jurnal Bisnis dan Manajemen, vol. 8, no. 2, pp. 151-162, 2018.

[11] J. Griffin, "Customer Loyalty: How to Earn It, How to Keep It, New York: Simon and Chuster," ed: Inc, 1996.

[12] N. P. Wulandari, Moeliono, "Analisis Faktor-faktor penggunaan layanan mobile banking di Bandung," Majalah Bisnis Dan IPTEK, vol. 10, no. 2, pp. 139-149, 2017.

[13] D. Social. (2015). MEF: Penggunaan Mobile Banking Capai 80\% di Indonesia, Isu Kepercayaan Menjadi Masalah Terbesar. Available: Available: https://dailysocial.id/post/mobile-banking-indonesia.

[14] B. T. P. Nasional. (2017). Laporan Tahunan 2017 Bank BTPN. Available: report/in/btpnar2017 ind r.pdf

[15] A. Ansari and A. Riasi, "Modelling and evaluating customer loyalty using neural networks: Evidence from startup insurance companies," Future Business Journal, vol. 2, no. 1, pp. 15-30, 2016.

[16] T. Zhang, B. Yuan, and W. Liu, "Predicting credit card customer loyalty using artificial neural networks," in 11th Joint International Conference on Information Sciences, 2008: Atlantis Press.

[17] A. N. Khan, A. Ali, "Factors affecting retailer's adopti on of mobile payment systems: A SEM-neural network modeling approach," Wireless Persona Communications Journal, vol. 103, no. 3, pp. 2529-2551, 2018.

[18] L. Maria, Badea , "Predicting consumer behavior with artificial neural networks," Procedia Economics Finance Journal, vol. 15, pp. 238-246, 2014.

[19] F. Liébana-Cabanillas, et al., "A SEM-neural network approach for predicting antecedents of m-commerce acceptance," International Journal of Information Management, vol. 37, no. 2, pp. 14-24, 2017.

[20] A. Lotko, et al., "Using Neural Networks in Modeling Customer Loyalty in Passenger Cars Maintenance and Repair Services," Applied Sciences Journal, vol. 8, no. 5, p. 713, 2018.

[21] C. Lee, et al., "Structured neural network techniques for modeling loyalty and profitability," Proceedings of SAS User Group International, pp. 082-30, 2005.

[22] A. Larasati, et al., "The application of neural network and logistics regression models on predicting customer satisfaction in a studentoperated restaurant," Procedia-Social Behavioral Sciences, vol. 65, pp. 94-99, 2012. 
[23] M. N. Greene, P. H. Morgan, G. R. Foxall, "NEURAL Networks and consumer behavior: NEURAL models, logistic regression, and the behavioral perspective model," The Behavior Analyst Journal, vol. 40, no. 2, pp. 393-418, 2017.

[24] Y. Deliana, I. A. Rum, "Understanding consumer loyalty using neural network," Polish Journal of Management Studies, vol. 16, no.2, pp. 5161, 2017.

[25] W. Anggraeni, R. Hendrawan, and R. Dewi, "Analisis Faktor-Faktor Yang Berpengaruh Pada Loyalitas Pelanggan Dengan Mengunakan Metode Jaringan Saraf Tiruan Untuk Pengambilan Keputusan Hotel XYZ," 2011.

[26] S. P. P. Indonesia, "Metode Penelitian Kombinasi (Mix Methods)," ed: Bandung: Alfabeta, 2015.

[27] D. a. Satori, Komariah, "Metodologi penelitian kualitatif," Bandinug: Afabeta, vol. 22, 2009.

[28] Badan Pengembangan dan Pembinaan Bahasa, "KBBI Daring," 2018.

[29] Y. Badudu and S. M. Zain, Kamus umum bahasa Indonesia. Pustaka Sinar Harapan, 1994.

[30] J. W. Kincaid, Customer relationship management: getting it right! Prentice Hall Professional, 2003.

[31] M. Srivastava, A. Rai, "Mechanics of engendering customer loyalty: A conceptual framework," IIMB management review, vol. 30, no. 3, pp. 207-218, 2018.

[32] R. T. Wigand, "Electronic commerce: Definition, theory, and context,"
The information society Journal, vol. 13, no. 1, pp. 1-16, 1997.

[33] M. Mia, et al,, "E-Banking: Evolution, Status and Prospect," The Cost Management Journal, vol. 35, no. 1, pp. 36-48, 2007.

[34] I. M. Al-Jabri, M. S. Sohail, "Mobile banking adoption: Application of diffusion of innovation theory," Journal of Electronic Commerce Research, vol. 13, no. 4, pp. 379-391, 2012.

[35] A. A. Shaikh, H. Karjaluoto, "Mobile banking adoption: A literature review," Telematics informatics Journal, vol. 32, no. 1, pp. 129-142, 2015.

[36] M. W. Gardner, S. Dorling, "Artificial neural networks (the multilayer perceptron) - a review of applications in the atmospheric sciences," Atmospheric environment Journal, vol. 32, no. 14-15, pp. 2627-2636, 1998.

[37] G. Anuraga, B. W. Otok, "Pemodelan Kemiskinan di Jawa Timur Dengan Structural Equation Modeling-Partial Least Square," Jurnal Statistika Universitas Muhammadiyah Semarang, vol. 1, no. 2, pp. 2227, 2013.

[38] J. F. Hair, et al., A primer on partial least squares structural equation modeling (PLS-SEM). Sage publications, 2016.

[39] W. Abdillah, Hartono, "Alternatif structural equation modeling (SEM) dalam penelitian bisnis," Yogyakarta: Andi, 2015.

[40] Yana, H. Rusdhi, M. Wibowo, "Analysis of factors affecting design changes in construction project with Partial Least Square (PLS)," Procedia Engineering, vol. 125, pp. 40-45, 2015. 
